\title{
An inventory of epigeal ants of the western Soutpansberg Mountain Range, South Africa
}

\begin{tabular}{|c|c|}
\hline \multicolumn{2}{|c|}{$\begin{array}{l}\text { Authors: } \\
\text { Thinandavha C. Munyai }{ }^{1} \\
\text { Stefan H. Foord }{ }^{2}\end{array}$} \\
\hline \multicolumn{2}{|c|}{$\begin{array}{l}\text { Affiliations: } \\
{ }^{1} \text { Centre for Invasion Biology, } \\
\text { Department of Ecology } \\
\text { and Resource Management, } \\
\text { University of Venda, } \\
\text { South Africa }\end{array}$} \\
\hline \multicolumn{2}{|c|}{$\begin{array}{l}{ }^{2} \text { Centre for Invasion Biology, } \\
\text { and South African Research } \\
\text { Chair for Biodiversity Value } \\
\text { and Change, Department of } \\
\text { Zoology, University of Venda, } \\
\text { South Africa }\end{array}$} \\
\hline \multicolumn{2}{|c|}{$\begin{array}{l}\text { Correspondence to: } \\
\text { Thinandavha Munyai }\end{array}$} \\
\hline \multicolumn{2}{|c|}{$\begin{array}{l}\text { Email: } \\
\text { caswell.munyai@univen.ac.za }\end{array}$} \\
\hline \multicolumn{2}{|c|}{$\begin{array}{l}\text { Postal address: } \\
\text { Private Bag X5050, } \\
\text { Thohoyandou 0950, } \\
\text { South Africa }\end{array}$} \\
\hline \multicolumn{2}{|c|}{$\begin{array}{l}\text { Dates: } \\
\text { Received: } 22 \text { July } 2014 \\
\text { Accepted: } 20 \text { Nov. } 2014 \\
\text { Published: } 30 \text { Mar. } 2015\end{array}$} \\
\hline \multicolumn{2}{|c|}{$\begin{array}{l}\text { How to cite this article: } \\
\text { Munyai, T.C. \& Foord, S.H., } \\
\text { 2015, 'An inventory of } \\
\text { epigeal ants of the western } \\
\text { Soutpansberg Mountain } \\
\text { Range, South Africa', Koedoe } \\
\text { 57(1), Art. \#1244, } 12 \text { pages. } \\
\text { http://dx.doi.org/10.4102/ } \\
\text { koedoe.v57i1.1244 }\end{array}$} \\
\hline \multicolumn{2}{|c|}{$\begin{array}{l}\text { Copyright: } \\
\text { (C) 2015. The Authors. } \\
\text { Licensee: AOSIS } \\
\text { OpenJournals. This work } \\
\text { licensed under the Creati } \\
\text { Commons Attribution } \\
\text { License. }\end{array}$} \\
\hline \multicolumn{2}{|l|}{ Read online: } \\
\hline 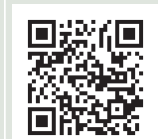 & $\begin{array}{l}\text { Scan this QR } \\
\text { code with your } \\
\text { smart phone or } \\
\text { mobile device } \\
\text { to read online. }\end{array}$ \\
\hline
\end{tabular}

The distribution, abundance and sensitivity of invertebrates to habitat change are largely unknown. Long-term monitoring of ecological gradients with standardised and comparable protocols can form the basis of a better understanding. Altitudinal gradients are particularly relevant within this context. Here we provide a check list and baseline data for ant species collected over a 5-year period across the Soutpansberg Mountain Range, South Africa. Standardised pitfall surveys across 11 sites yielded a total of 133 species in 38 genera and 6 subfamilies. Sample coverage of epigeal ants was 0.98 for the transect as a whole. Of these species, $21 \%$ were restricted to the southern slope of the mountain and $14 \%$ to the northern slope. Extrapolated richness estimates reached an asymptote for all, except for three sites. These were the only sites impacted by bush encroachment. Observed richness was the highest at a low-altitude mesic site that is exposed to considerable disturbance by megaherbivores and mechanical clearing of woody vegetation. Structural classification of vegetation was predictive of a broad-scale ant assemblage structure. On a smaller scale, however, structure was a function of elevation, space and temperature.

Conservation implications: Future monitoring should target indicator taxa associated with bush encroachment, particularly with reference to their impacts on grasslands. Bush encroachment could endanger several ant species associated with mesic grasslands and woodlands on the mountain, as well as ant diversity, as these were the habitats with the highest ant diversity.

\section{Introduction}

Although invertebrates comprise the bulk of diversity in an ecosystem, they are often excluded from conservation initiatives. Cardoso et al. (2011) identified seven reasons for this. Three of the shortfalls had to do with: (1) the distribution of invertebrate species is unknown (Wallacean), (2) invertebrate abundance and their changes in space and time are unknown (Prestonian) and (3) invertebrates' way of life and sensitivity to habitat types are largely unknown (Hutchinsonian). These three shortfalls are particularly relevant to how ecologists practise their science, as the distribution, abundance in time and space, and sensitivities to habitat change are largely unknown for most species. These constraints can be resolved through inventories that follow standardised and comparable protocols (Cardoso et al. 2011).

Ants respond to the environment at small scales and considerable support exists for their use as indicators of disturbance and habitat degradation (see Andersen \& Majer [2004] for review). Ants are easily collected and species or morpho-species level determination are aided through readily available taxonomic expertise (Ward 2010). In addition to being diverse, abundant and a dominant component of animal biomass in terrestrial ecosystems (Hölldobler \& Wilson 1990), they also perform important functions in ecosystems, including pollination, myrmechory and nutrient cycling, among others (Wielgoss et al. 2014).

The Soutpansberg Mountain Range is a centre of endemism (Hahn 2002) and is the focal point for the newly proclaimed Vhembe Biosphere Reserve, one of the United Nations Educational, Scientific and Cultural Organisation (UNESCO) World Network of Biosphere Reserves (www. unesco.org). It has the highest plant generic and family level diversity among the 18 recognised Centres of Plant Endemism in southern Africa (Van Wyk \& Smith 2001). Recent results suggest that this diversity and endemism is mirrored by spiders (Foord 2008) and reptiles (Kirchhof et al. 2010). As an inselberg that rises $1000 \mathrm{~m}$ above the surrounding plains, the Soutpansberg Mountain Range has provided a refuge for several taxa during periods of climate change and will once more play a biogeographic role in the region as regional climate changes take effect in response to elevated global greenhouse gases (Tshiala et al. 2011). 
Transects can provide valuable diversity, distribution and abundance information as well as population trends. Altitudinal transects are particularly relevant within the context of contemporary climate changes. Here we summarise the results of a standardised inventory of epigeal ants over a 5-year period (2009-2013), along a transect across the western Soutpansberg Mountain Range. We provide a checklist of epigeal ants with a sample coverage of 0.98 for the whole transect. A posteriori defines distinct ant assemblages across the transect and tests for differences between these groups.

\section{Materials and methods \\ Study area}

The $16.5 \mathrm{~km}$ altitudinal transect extends over the highest point of the Soutpansberg Mountain Range, Lajuma (1748 m), in the Luvhondo Nature Reserve. It includes the northern and southern slopes of the mountain and consists of 11 sites, spaced at $200 \mathrm{~m}$ altitudinal intervals. It starts at $800 \mathrm{~m}$ a.s.l. in the Limpopo valley to the north of the mountain, ascends $900 \mathrm{~m}$ to Lajuma, and descends another $800 \mathrm{~m}$ to the plains south of the range (Figure 1).

The study area stretches across five broad structural vegetation types, namely woodland, sedgeland-herbland, forest, thicket and shrubland. All the sites on the northern aspect are woodland (total tree cover $0.1 \%-75 \%$; shrub cover
$<10 \%$; mean crown-gap ratio $>0.1)$. They can be characterised as low (1 m-5 m-tall trees), open (crown-gap ratio of 2-8.5) and woodland (Figures 2a-2d), mostly on shallow quartzitic soils (Figures $2 \mathrm{~b}-2 \mathrm{~d}$ ). One site is characterised by deep sandy soils (Figure 2a). Dominant trees species include Burkea africana, Ochna pulchra, Diospyros dichrophylla, Rhus magalismontanum, Boscia albitrunca, Adansonia digitata, Acacia nigrescens and Terminalia sericea.

Vegetation types along the plains and lower southern foothills are largely thicket (Figure 3d) and shrubland (Figure 3e), located on red loamy-clay soils dominated by woody species such as Dichrostachys cinerea, Acacia caffra and Olea europaea.

Structurally, the lowest site on the southern aspect (Figure 3e) is tall, closed shrubland $(<0.1 \%$ tree cover). It is dominated by a $D$. cinerea matrix with patches that are mechanically cleared of all woody plants. Site $10 \mathrm{~S}$ (Figure 3d) is low thicket $(10 \%-100 \%$ tree cover and $>10 \%$ shrub cover). The forests are found at mid-elevation, between $1200 \mathrm{~m}$ a.s.l. and $1400 \mathrm{~m}$ a.s.l. on the southern slope and include both short (Figure 3c) and tall (Figure $3 b$ ) forest sites with a crown-gap ratio of $<0.1$. They are dominated by woody species such as Croton sylvaticus and Ekebergia capensis. The higher elevational zones of the southern aspect and summit consist of a sedgeland-herbland matrix with low shrubland patches that grow on shallow rocky soils on quartzite, dominated by Coleochloa species (Figures 2e-3a).

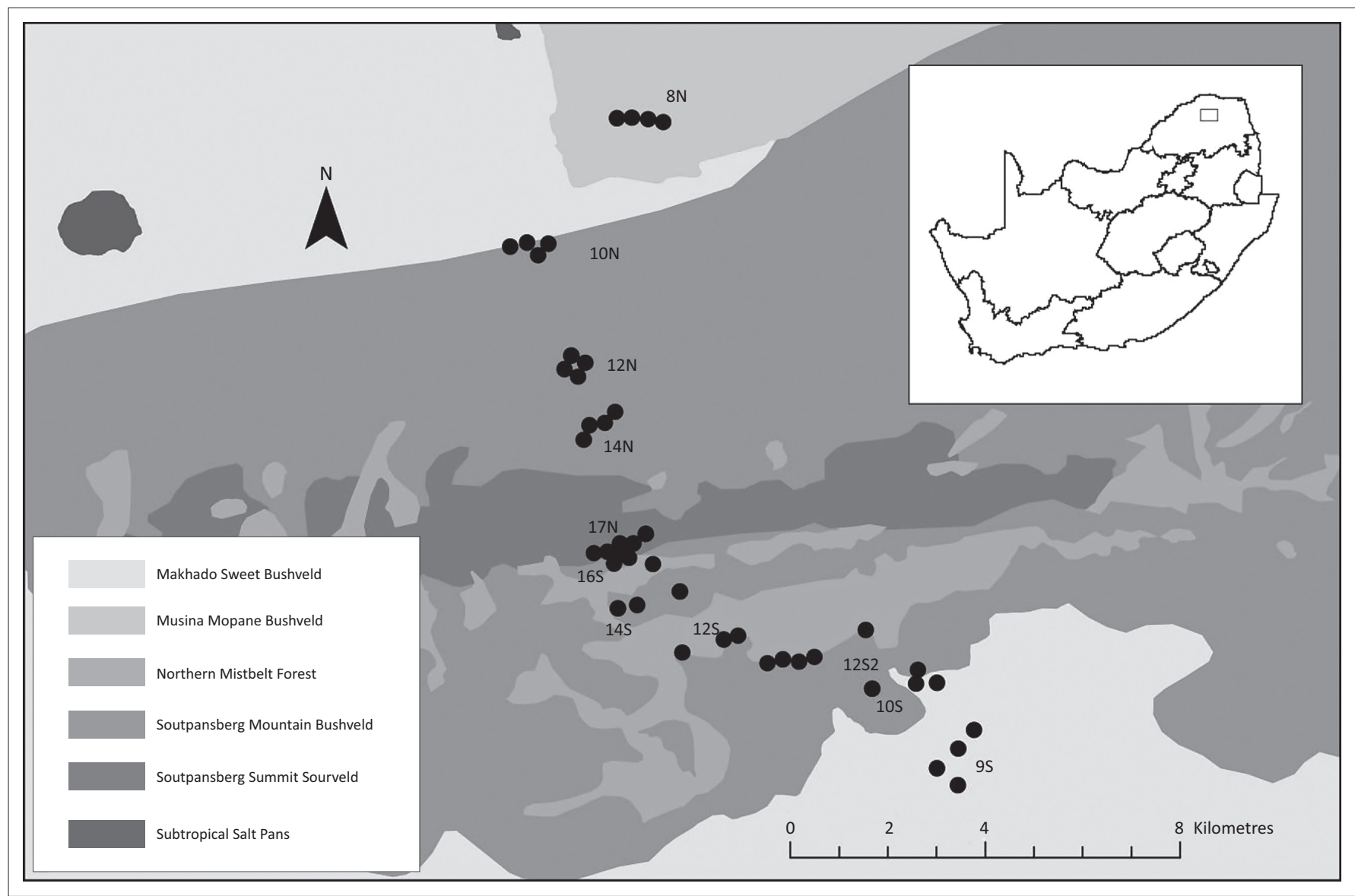

Northern aspect: $800 \mathrm{~m}$ a.s.l. (8N), $1000 \mathrm{~m}$ a.s.I. (10N), $1200 \mathrm{~m}$ a.s.I. (12N), $1400 \mathrm{~m}$ a.s.l. (14N), $1700 \mathrm{~m}$ a.s.l. (17N/summit); southern aspect: $1600 \mathrm{~m}$ a.s.I. (16S), $1400 \mathrm{~m}$ a.s.l. (14S), $1200 \mathrm{~m}$ a.s.l.. (12S), $1200 \mathrm{~m}$ a.s.I. (12S2), $1000 \mathrm{~m}$ a.s.I. (10S), $900 \mathrm{~m}$ a.s.I. (9S).

FIGURE 1: Location of the Soutpansberg transect in South Africa (inset) and the position of the 44 replicates with the 5 structural habitat types. 

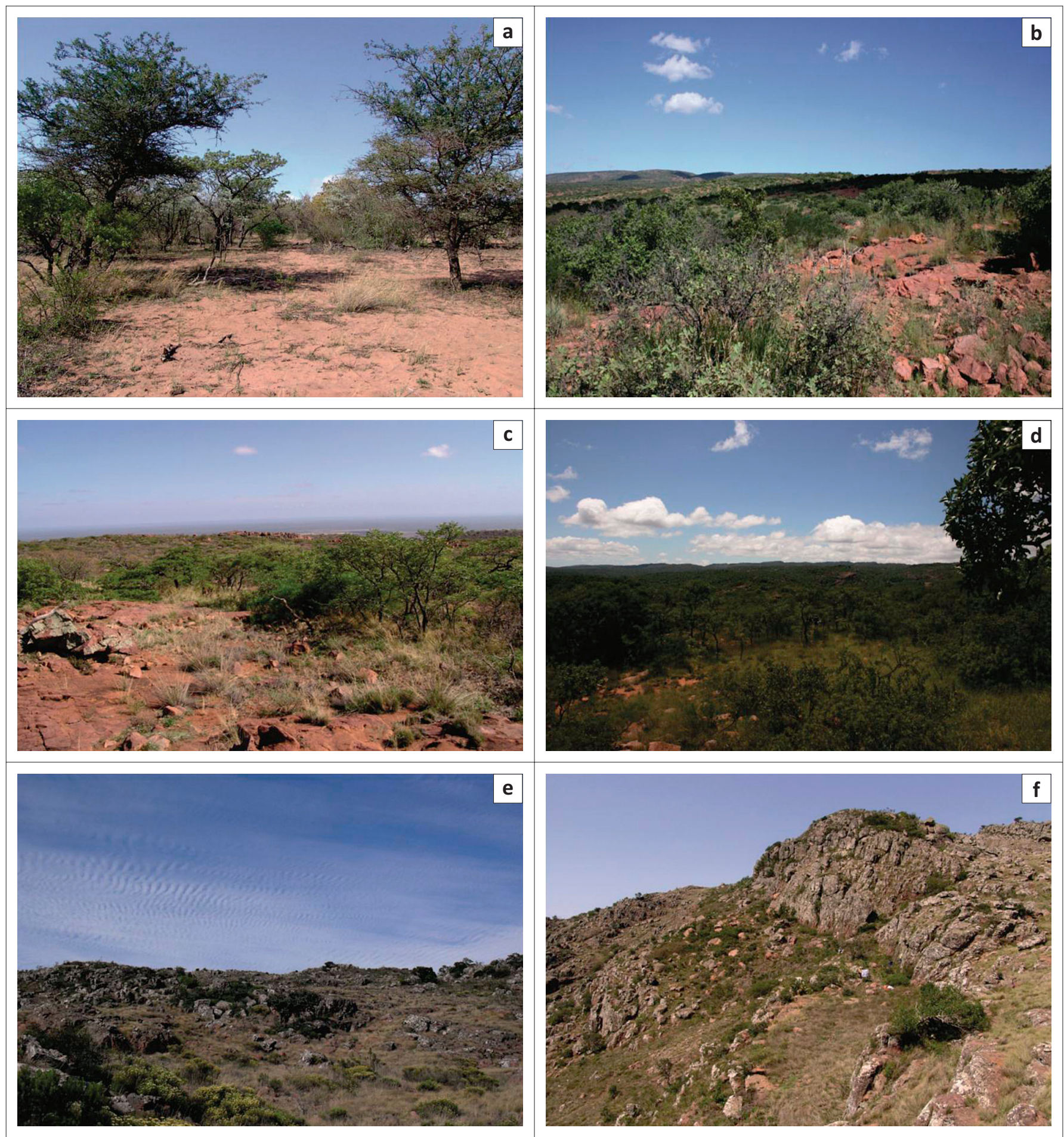

FIGURE 2: (a) $08 \mathrm{~N}$ and (b) $12 \mathrm{~N}$ deep sandy soils characterised by trees such as Adansonia digitata, Acacia nigrescens and Terminalia sericea. (c) $10 \mathrm{~N}$ and (d) $14 \mathrm{~N}$ are on shallow quartzitic soils and include Burkea africana, Ochna pulchra, Diospyros dichrophylla, Rhus magalismontanum, Boscia albitrunca and Terminalia sericea. Higher elevation sites (e) $17 \mathrm{~N}$ and (f) $16 \mathrm{~S}$ low shrubland patches with shallow rocky soils on quartzite, dominated by Coleochloa species.

Soil temperature extremes were the highest on the summit of the mountain (mean annual range $10{ }^{\circ} \mathrm{C}-55^{\circ} \mathrm{C}$ ) and the lowest in the tall forests of the southern aspect $\left(14^{\circ} \mathrm{C}-32^{\circ} \mathrm{C}\right)$.

\section{Ant sampling}

Ants were sampled through standardised pitfall trapping (Munyai \& Foord 2012) at each of the 11 sites. Sample units consisted of 10 pitfall traps (ø $62 \mathrm{~mm}$ ) laid out in a sampling grid $(2 \times 5)$ with $10 \mathrm{~m}$ spacing between traps.
Pitfall traps were left open for 5 days, since it is considered representative and does not sample excessive ants (see Munyai \& Foord [2012] and references therein). From September 2009 onwards (Appendix 1), sampling units were spatially replicated four times at each site. Replicates were separated by $<300 \mathrm{~m}$ to avoid pseudo-replication (Ness et al. 2004). The traps contained a 50\% solution of propylene glycol because it neither attracts nor repels ants (Abensperg-Traun \& Steven 1995). 

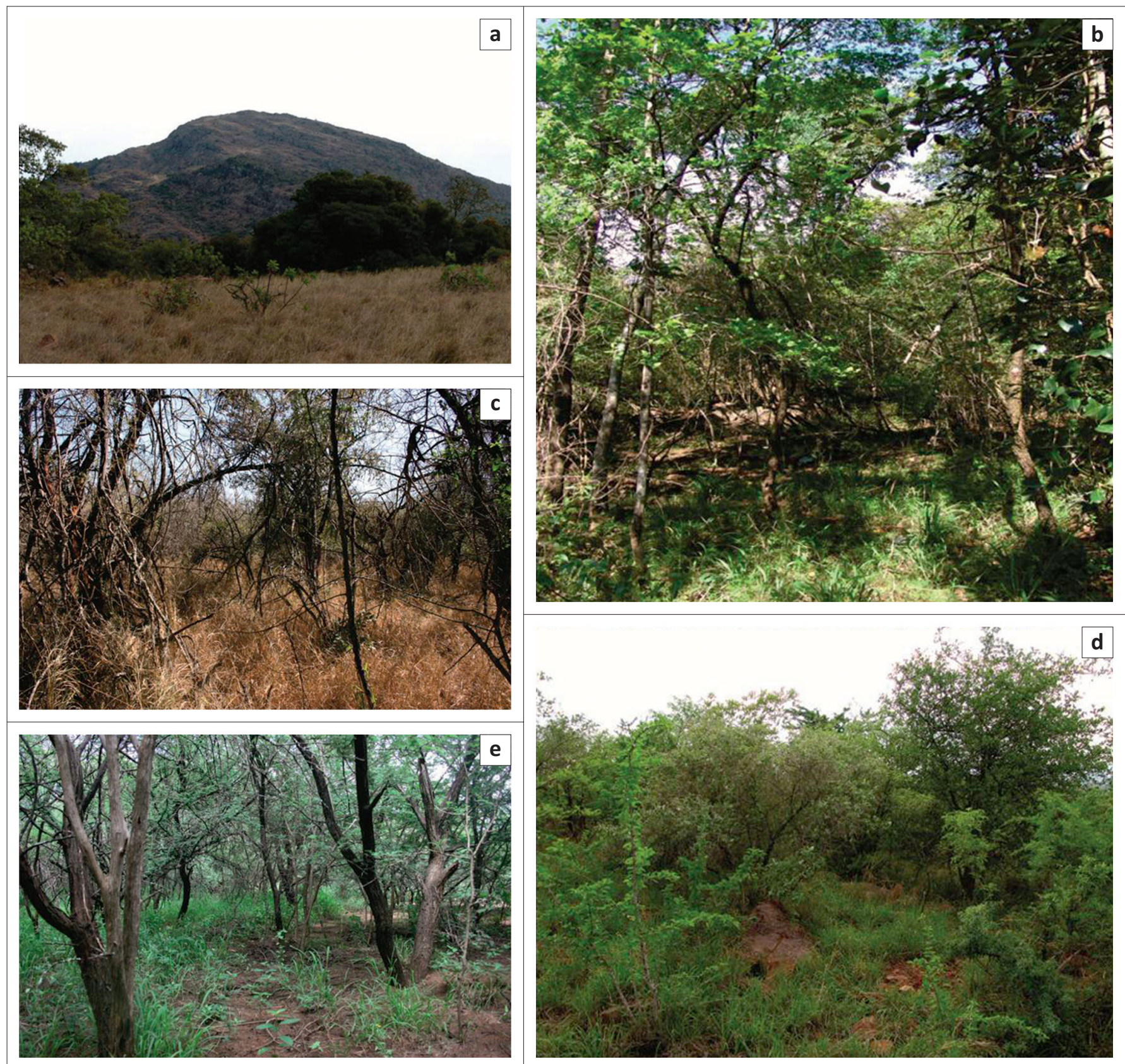

FIGURE 3: (a) Low shrubland patches (14S) with shallow rocky soils on quartzite, dominated by Coleochloa species. (b) Tall forest (12S) dominated by woody species of Croton sylvaticus and Ekebergia capensis. (c) Short forest (12S2). Low elevation sites: (d) Thicket site (10S) on clay soils dominated by woody species such as Acacia caffra and Olea europaea. (e) Shrubland (09S) on clay soils dominated by woody species such as Dichrostachys cinerea.

The ant samples were washed in a laboratory and stored in $70 \%$ ethanol. They were sorted to morpho-species and, where possible, identified to species by comparison with reference collections housed in the Kruger National Park in South Africa and the Commonwealth Scientific and Industrial Research Organisation (CSIRO) Tropical Ecosystems Research Centre in Darwin, Australia. Bolton (1994) was used to identify some specimens to genus level, while valid names were confirmed using AntCat (http:// www.antcat.org) and AntWeb (http://www.antweb.org). The unidentified (morpho) species were given the following number codes: University of Venda Collection_01, 02, etc. (i.e. UVOC_01, 02, etc.).
Bothroponera, Mesoponera, Ophthalmopone and Pseudoponera were considered valid genera rather than being subsumed under Pachycondyla (Schmidt \& Shattuck 2014). Subfamilies Aenictinae and Cerapachyinae were both considered invalid and therefore subsumed under Dorylinae, as treated by Brady et al. (2014). Reference collections are housed at the University of Venda and CSIRO Tropical Ecosystems Research Centre (Darwin, Australia).

\section{Data analysis}

Chao 2 and ICE, in EstimateS version 9.1.0 (Colwell 2013), were used to estimate species richness. Sample coverage at each site and the transect as a whole was done with 
TABLE 1: Observed number of species, abundance, richness estimates (Chao 2 and ICE, available in EstimateS 9.1.0 package) and sample coverage for broad structural vegetation types and 11 sites with their geographical coordinates along the Soutpansberg transect.

\begin{tabular}{|c|c|c|c|c|c|c|c|c|}
\hline Vegetation types & Obs & Abundance & Site & Geographical coordinates & Obs & Chao 2 & ICE & Sample coverage \\
\hline Shrubland & 77 & 4966 & $9 \mathrm{~S}$ & $2303.846^{\circ} \mathrm{S}, 2929.400^{\circ} \mathrm{E}$ & 77 & 87.9 & 85.5 & 0.974 \\
\hline Thicket & 60 & 16192 & $10 \mathrm{~S}$ & $2302.961^{\circ} \mathrm{S}, 2928.680^{\circ} \mathrm{E}$ & 60 & 79.3 & 75.1 & 0.968 \\
\hline \multirow[t]{2}{*}{ Forest } & 68 & 8578 & $12 S 2$ & $2302.661^{\circ} \mathrm{S}, 2927.869^{\circ} \mathrm{E}$ & 56 & 74.9 & 72.9 & 0.958 \\
\hline & - & - & $12 S$ & $2302.417^{\circ} \mathrm{S}, 2927.033^{\circ} \mathrm{E}$ & 52 & 58.1 & 57 & 0.955 \\
\hline \multirow[t]{3}{*}{ Sedgeland-herbland } & 85 & 15948 & $14 S$ & $2302.071^{\circ} \mathrm{S}, 2925.863^{\circ} \mathrm{E}$ & 63 & 79.1 & 80 & 0.968 \\
\hline & - & - & $16 \mathrm{~S}$ & $2301.355^{\circ} \mathrm{S}, 2926.033^{\circ} \mathrm{E}$ & 55 & 75.9 & 85.5 & 0.959 \\
\hline & - & - & $17 \mathrm{~N}$ & $2301.445^{\circ} \mathrm{S}, 2925.745^{\circ} \mathrm{E}$ & 41 & 49.8 & 48.5 & 0.963 \\
\hline \multirow[t]{4}{*}{ Woodland } & 92 & 40023 & $14 N$ & $2300.018^{\circ} \mathrm{S}, 2925.545^{\circ} \mathrm{E}$ & 63 & 84.4 & 84 & 0.969 \\
\hline & - & - & $12 \mathrm{~N}$ & $2259.504^{\circ} \mathrm{S}, 2925.421^{\circ} \mathrm{E}$ & 64 & 71 & 67.7 & 0.98 \\
\hline & - & - & $10 \mathrm{~N}$ & $2258.157^{\circ} \mathrm{S}, 2924.979^{\circ} \mathrm{E}$ & 57 & 70 & 68.1 & 0.972 \\
\hline & - & - & $8 \mathrm{~N}$ & $2256.683^{\circ} \mathrm{S}, 2926.359^{\circ} \mathrm{E}$ & 57 & 68 & 64.3 & 0.982 \\
\hline
\end{tabular}

Obs, observed number of species.

sample-based rarefaction and extrapolation of the incidence matrix. Sample coverage represents the proportion of the total number of individuals in the ant assemblage along the transect that belong to the species represented in our sample (Chao \& Jost 2012).

Both interpolation and extrapolation of samples was based on the Bernoulli product model as well as unconditional variance estimates for the rarefaction (interpolation) (Chao \& Jost 2012) and extrapolation curves. This sample-based estimation provides both unconditional variance abundance data of this study and species richness predicted by a 1000 pitfall samples and were considered to be a fair reflection of the richness at a site.

Samples within each replicate were pooled over the period of the study for multivariate analysis. Ant assemblage structure was mapped using non-metric multidimensional scaling of Bray-Curtis similarity measures (Clarke \& Gorley 2006). A posteriori groups of ant assemblages were defined based on hierarchical clustering with group average linking. Support for these groups was tested with the permutational procedure SIMPROF in PRIMER version 6.1.6 (Clarke \& Gorley 2006).

\section{Results}

In total, 85759 ant specimens were collected during the 13 sampling periods (Appendix 2), comprising 133 species in 38 genera and 6 subfamilies.

Myrmicinae (with 72 species, $86 \%$ of the total abundance and 15 genera) was the most diverse and abundant subfamily, followed by Formicinae (27 species and 6 genera). Ponerinae (12 genera) had the second highest generic diversity.

The most specious genera were Tetramorium (22 species), Camponotus (19 species), Monomorium (13 species), Pheidole (9 species), Crematogaster (6 species), Meranoplus (4 species), and Ocymyrmex, Anochectus, Bothroponera and Plectroctena, each with 3 species (Appendix 2).

Sample-based species rarefaction and extrapolation curves for the transect as a whole approximated an asymptote, indicating that most of the epigeal species were collected

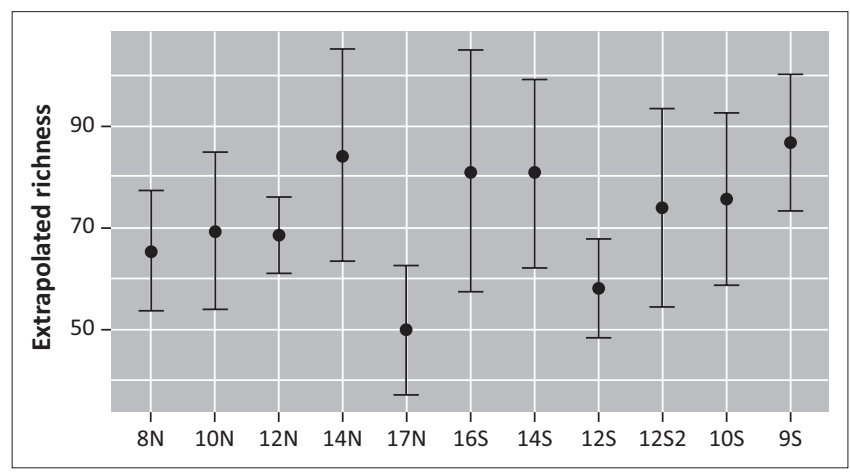

FIGURE 4: Extrapolated species richness for each site and $95 \%$ confidence intervals based on unconditional variance, from 1000 pitfall samples for each of the 11 sites across the Soutpansberg Mountain Range.

with a sample coverage of 0.98 . Sample coverage for all sites was $>0.95$, while the forest site $12 \mathrm{~S}$ coverage was the lowest, at 0.955 . Based on richness estimations (Table 1) and species richness extrapolations (Figures 4 and 5), ant richness peaked at mid-elevations on the northern aspect. Only at woodland site $14 \mathrm{~N}$ was species richness significantly greater that of $17 \mathrm{~N}$, the summit (Figure 4).

The pattern on the southern aspect was more complex, with richness decreasing significantly from shrubland site $9 \mathrm{~S}$ to forest site $12 \mathrm{~S}$ (Figure 4) and then increasing at sedgeland sites $14 \mathrm{~S}$ and $16 \mathrm{~S}$ before decreasing again towards the summit (Figure 4). Based on predicted richness of sites (Figure 5), the ranking of sites changes only for $14 \mathrm{~N}$. Notably, the predicted curve for $16 \mathrm{~S}$ also suggests a considerable increase in richness with increased sampling. The sites with the highest and lowest variation in mean annual temperature variation (17N and $12 \mathrm{~S})$ also had the lowest species richness.

In total, 104 species were collected along the northern slope and 117 species on the southern slope. Twenty-eight species were restricted to the southern slope and nineteen species to the northern slope. Ten species, Camponotus UOVC_18 (maculatus gp.), Lepisiota UOVC_01 (capensis gp.), Monomorium albopilosum Emery, Monomorium UOVC_07, Monomorium_08 (monomorium gp.), Pheidole UOVC_01 (megacephala gp.), Tetramorium cf. setigerum Mayri, Tetramorium UOVC_01 (squaminode gp.), Tetramorium UOVC_08 (simillimum gp.) 


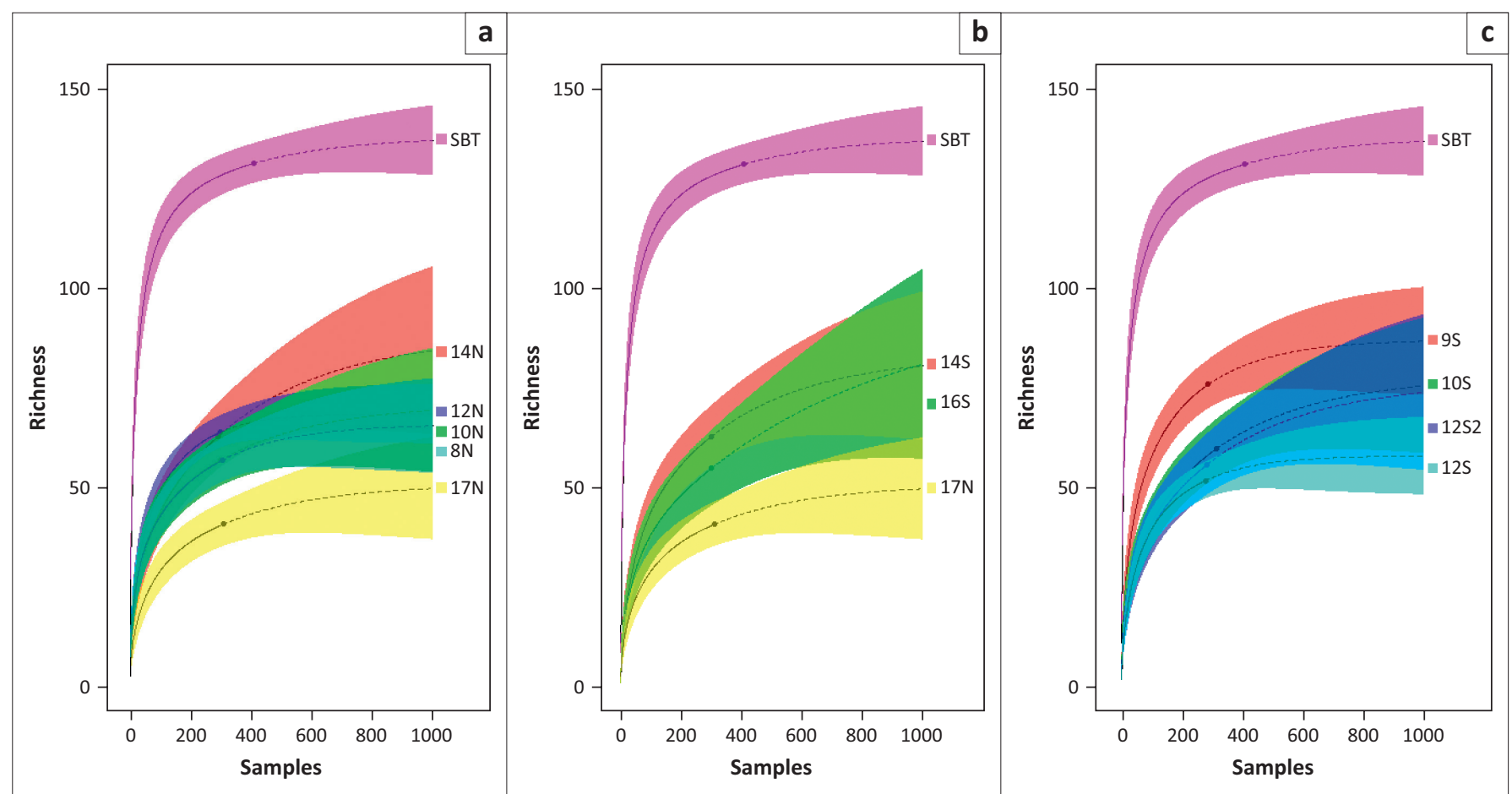

FIGURE 5: Species accumulation curves and their 95\% confidence intervals for 1000 samples per site. The solid circles represent reference samples; solid lines are rarefied samples and dashed lines are extrapolation based on Mau Tau estimation. (a) Northern aspect, (b) higher elevational sites and (c) low to mid-elevation southern aspect. SBT, accumulation curve for the whole transect.

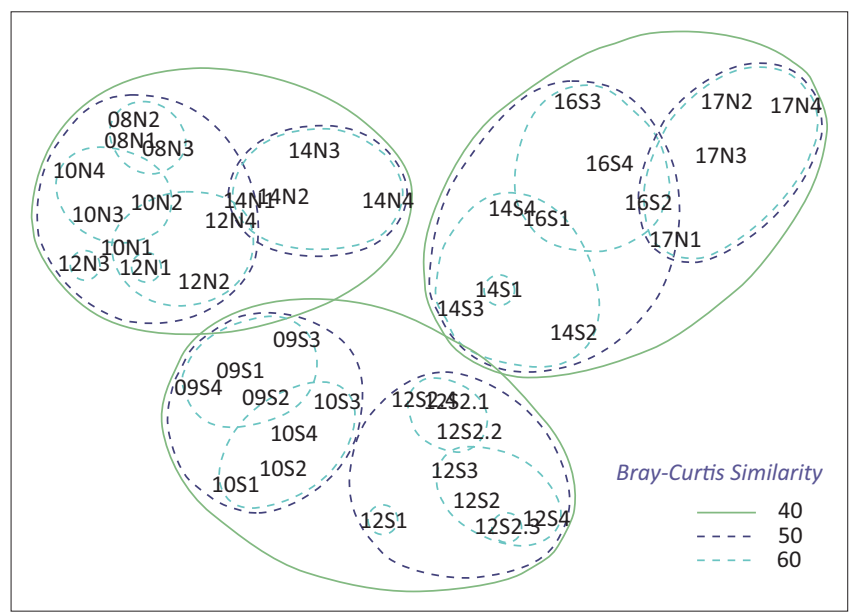

Stress $=0.12$.

FIGURE 6: Non-metric multidimensional scaling of ant assemblages for samples pooled within each of the 44 replicates across 11 sampling sites in the Soutpansberg Mountain Range.

and Technomyrmex pallipes Smith, occurred at all the sites (Appendix 2).

A total of 20 Ponerine species were sampled from both the southern and the northern aspects. Fifty per cent of all Ponerine species, namely Anochectus UOVC_01, Bothroponera ?strigulosa Emery, Bothroponera UOVC_02, Bothroponera UOVC_03, Hypoponera UOVC_01, Leptogenys intermedia Emery, Leptogenys schwabi Forel, Ophthalmopone UOVC_01, Plectroctena UOVC_02 and Pseudoponera UOVC_01, were restricted to the southern slope of the mountain. The other 10 species occurred on both slopes of the mountain.
The non-metric multidimensional scaling plot identified three major groupings: the high elevation sedgeland-herbland sites (14S - summit); woodlands (08N - 14N); and shrubland, thicket and forest sites (09S - 12S) (Figure 6). At Bray-Curtis similarity measures of 50 , each of the 3 groups divides into 2 (Figure 6). The groupings reveal distinct assemblages associated with the summit $(17 \mathrm{~N})$ at higher elevations, while $14 \mathrm{~N}$ was distinct from all the lower elevation sites on the northern aspect. Low elevation (shrubland and thicket sites 09S - 10S) and mid-elevation (forest sites 12S2 - 12S) of the southern aspect formed a distinct grouping.

\section{Discussion}

The level and higher taxon diversity of this study compares favourably with that of similar studies in the Cederberg and Drakensberg mountains, both of which employ a protocol similar to this study. The Cederberg transect located in the Cape Floristic Kingdom includes 17 sites over a distance of $160 \mathrm{~km}$. That study recorded 86 species in 24 genera (Botes et al. 2006). The transect in the grasslands of the Drakensberg, with 9 elevational sites over a distance of $104 \mathrm{~km}$ along the Sani Pass, collected 98 species in 28 genera and 7 subfamilies (Bishop et al. 2014). Only one other study of ants along an altitude exists for the Savanna Biome in South Africa, where Schoeman \& Foord (2012) found 104 species in 29 genera along a $1000 \mathrm{~m}$ elevational range in the Marakele National Park. With a higher generic plant diversity than the Cape Floristic Kingdom (Hahn 2006) and 90\% of all spider families found in the Savanna Biome (Foord et al. 2011), the Soutpansberg is characterised by rich, higher taxon diversity. 
Myrmicinae and Formicinae were the most diverse subfamilies. The most speciose genera were Tetramorium, Camponotus, Pheidole and Monomorium. This conforms to results from other studies in South Africa (Botes et al. 2006). Monomorium is very diverse in Australia, while Camponotus and Pheidole are the most diverse in Brazil (Campos et al. 2011), although the highly diverse genus in Australia, Polyrhachis, is only represented by two species along this transect. Except for Lepisiota, genera found throughout the transect belong to cosmopolitan genera (Camponotus, Monomorium, Pheidole and Tetramorium).

Most of the species accumulation curves of predicted richness based on 1000 pitfall samples reached an asymptote. There were two exceptions: a woodland site $14 \mathrm{~N}$ and sedgeland site $16 \mathrm{~S}$, both of which also had the lowest coverage. Although $14 \mathrm{~N}$ is in the woodland vegetation type, it is near the ecotone between sedgeland and woodland. The large turnover of taxa at this site could be the result of mass effects from taxa found in sedgeland. The steep slope of the $16 \mathrm{~S}$ accumulation curve might suggest a temporal change in the ant assemblages of this site. Based on photographic records at each of the pitfalls, the Coleochloa species that dominate this site are being invaded by short woody shrubs. Turnover at this site might be linked to this encroachment and could probably lead to increased abundance of taxa associated with sites that are structurally more complex, such as forest sites $12 \mathrm{~S}$ and 12S2 and shrubland site 9S. This has particularly important implications for the management of the few remaining grassland habitats in the Soutpansberg.

The high diversity of Ponerinae species at the base of southern aspect might be due to more productive ecosystems associated with the basalt intrusions, and higher rainfall. Disturbance also seems to positively impact Ponerine richness, which peaks in shrubland site 9S. This site is inside a wildlife sanctuary that is stocked with buffalo and where the bush is mechanically cleared. The three major groupings of ant assemblages across the study area conform to the broad structural classification of the vegetation used in this study (Edwards 1983).

\section{Conclusion}

This study provides a thorough inventory of grounddwelling ants, with a sample coverage of 0.98 . The sample coverage represents the proportion of the total number of individuals in the ant assemblage along the transect that belongs to the species represented in our sample (Chao \& Jost 2012). Extrapolated richness for most sites reached an asymptote, except for three sites. All three of these sites can be considered to be sites that have experienced increased levels of bush encroachment. This is particularly concerning at 16S, which represents some of the last remaining grassland habitats in the Soutpansberg.

Ant taxa that act as indicators of bush encroachment should be identified in order to monitor the rate of these impacts. A single site on the lowest elevation of the southern aspect
(09S) yielded $57 \%$ of the total ant species. This site experiences higher levels of disturbance through herbivory and bush clearing and provides support for the important role of disturbance as a driver of ant diversity in the Savanna Biome. The structural classification of vegetation in this study is a good predictor of broad-scale ant assemblage structure. Finer scale distinctions were linked to elevation, structural elements and temperature.

\section{Acknowledgments}

Special thanks to Alan Andersen and Hendrick Sithole for verifying ant identifications. We are grateful to Ian Gaigher (Lajuma Research Centre), Steven Fick (Koedoesvlei Farm) and Dave Dewsnap (Goro Nature Reserve) for providing access to their farms. Several volunteers from the University of Venda and Lajuma Research Centre are thanked for their assistance in the field. This study was funded by the DSTNRF Center of Excellence for Invasion Biology and the University of Venda.

\section{Competing interests}

The authors declare that they have no financial or personal relationships which may have inappropriately influenced them in writing this article.

\section{Authors' contributions}

T.C.M. (University of Venda) and S.H.F. (University of Venda) were responsible for the project design. T.C.M. identified the specimens. T.C.M. and S.H.F. performed the analysis and wrote the manuscript.

\section{References}

Abensperg-Traun, M. \& Steven, D., 1995, 'The effects of pitfall trap diameter on ant species richness (Hymenoptera: Formicidae) and species composition of the catch in a semi-arid eucalypt woodland', Journal of Ecology 20(2), 282-287.

Andersen, A.N. \& Majer, J.D., 2004, 'Ants show the way Down Under: Invertebrates as bioindicators in land management', Frontiers in Ecology and the Environment 2(6), 291-298. http://dx.doi.org/10.1890/1540-9295(2004)002[0292:ASTWDU] 2.0.CO;2

Bishop, T.R., Robertson, M.P., Van Rensburg, B.J. \& Parr, C.L., 2014, 'Elevation-diversity patterns through space and time: Ant communities of the Maloti-Drakensberg Mountains of southern Africa', Journal of Biogeography 41, 2256-2268. http://dx.doi.org/10.1111/jbi.12368

Bolton, B., 1994, Identification Guide to the Ant Genera of the World, Harvard University Press, Cambridge, Massachusetts.

Botes, A., Mcgeoch, M.A., Robertson, H.G., Van Niekerk, A., Davids, H.P. \& Chown S.L., 2006, 'Ants, altitude and change in the northern Cape Floristic Region' Journal of Biogeography 33, 71-90. http://dx.doi.org/10.1111/j.13652699.2005.01336.x

Brady, S.G., Fisher, B.L., Schultz, T.R. \& Ward, P.S. 2014 'The rise of army ants and their relatives: diversification of specialized predatory doryline ants', BMC Evolutionary Biology 14(5), 93. http://dx.doi.org/10.1186/1471-2148-14-93

Campos, R.I., Vasconcelos, H.L., Andersen, A.N., Frizzo, T.L.M. \& Spena, K.C. 2011, 'Multi-scale ant diversity in savanna woodlands: an intercontinental comparison', Austral Ecology 36, 983-992. http://dx.doi.org/10.1111/j.14429993.2011.02255.x

Cardoso, P., Erwin, T.L., Borges, P.A.V. \& New, T.R., 2011, 'The seven impediments in invertebrate conservation and how to overcome them', Biological Conservation 144, 2647-2655. http://dx.doi.org/10.1016/j.biocon.2011.07.024

Chao, A. \& Jost, L., 2012, 'Coverage-based rarefaction and extrapolation: standardizing samples by completeness rather than size', Ecology 93, 2533-2547. http://dx.doi. org/10.1890/11-1952.1

Clarke, K.R. \& Gorley, R.N., 2006, PRIMER v6: User Manual/Tutorial. PRIMER-E, Plymouth.

Colwell, R.K., 2013, EstimateS: Statistical estimation of species richness and shared species from samples. Version 9. Persistent URL <purl.ocls.org/estimates>. 
Edwards, D., 1983, 'A broad-scale structural classification of vegetation for practical purposes', Bothalia 14, 705-712.

Foord, S.H., 2008, 'Cladistic analysis of the Afrotropical Hersiliidae (Arachnida: Araneae) with the first records of Murricia and the description of a new genus from Madagascar', Journal of Afrotropical Zoology 4, 111-142.

Foord, S.H., Dippenaar-Schoeman, A.S., Haddad, C.R., Lotz, L.N. \& Lyle, R., 2011 'The faunistic diversity of spiders (Arachnida: Araneae) of the Savanna Biome in South Africa', Transactions of the Royal Society of South Africa 66, 170-201. http://dx.doi.org/10.1080/0035919X.2011.639406

Hahn, N., 2002, 'Endemic flora of the Soutpansberg', MSc thesis, Faculty of Science and Agriculture, University of KwaZulu-Natal.

Hahn, N., 2006, 'Floristic diversity of the Soutpansberg, Limpopo Province, South Africa', $\mathrm{PhD}$ thesis, Faculty of Natural and Agricultural Sciences, University of Pretoria.

Hölldobler, B. \& Wilson, E.O., 1990, The Ants, Harvard University Press, Cambridge, Massachusetts. http://dx.doi.org/10.1007/978-3-662-10306-7

Kirchhof, S., Kramer, M., Linden, J. \& Richter, K., 2010, 'The reptile species assemblage of the Soutpansberg (Limpopo Province, South Africa) and its characteristics', Salamandra 46, 147-166.

Munyai, T.C. \& Foord, S.H., 2012, 'Ants on a mountain: spatial, environmental and habitat associations along an altitudinal transect in a centre of endemism', Journal of Insect Conservation 16(5), 677-695. http://dx.doi.org/10.1007/s10841-011-9449-9
Ness, J.H., Bronstein, J.L., Andersen, A.N. \& Holland, J.N., 2004, 'Ant body size predicts dispersal distance of ant-adapted seeds: Implications of small-ant invasions', Ecology 85, 1244-1250. http://dx.doi.org/10.1890/03-0364

Schmidt, C.A. \& Shattuck, S.O., 2014, 'The Higher Classification of the Ant Subfamily Ponerinae (Hymenoptera: Formicidae), with a Review of Ponerine Ecology and Behavior', Zootaxa 3817(1), 001-242. http://dx.doi.org/10.11646/ zootaxa.3817.1.1

Schoeman, C.S. \& Foord, S.H., 2012, 'A checklist of epigaeic ants from Marakele National Park, Limpopo Province, South Africa (Hymenoptera: Formicidae)', Koedoe 54(1), 1-7. http://dx.doi.org/10.4102/koedoe.v54i1.1030

Tshiala, M.F., Olwoch, J.M. \& Engelbrecht, F.A., 2011, 'Analysis of Temperature Trends over Limpopo Province, South Africa', Journal of Geography and Geology 3 13-21. http://dx.doi.org/10.5539/jgg.v3n1p13

Van Wyk, A.E. \& Smith, G.F., 2001, Regions of Floristic Endemism in Southern Africa, Umdaus Press, Pretoria.

Ward, P.S., 2010, 'Taxonomy, phylogenetics, and evolution', in L. Lach, C.L. Parr \& K.L. Abbott (eds.), Ant Ecology, pp. 3-17, Oxford University Press, New York.

Wielgoss, A., Tscharntke, T., Rumede, A., Fiala, B., Seidel, H., Shahabuddin, S. et al., 2014, 'Interaction complexity matters: Disentangling services and disservices of ant communities driving Viy in tropical agreecosystems', Proceedings of the Royal Society B: Biological Sciences 281, 2013-2144. 


\section{Appendix 1}

TABLE A1: Summary of the number of replicates set out at each of the 11 sites during each of the 13 surveys along the Soutpansberg Mountain Range. A replicate within a site consisted of 10 pitfalls in a $2 \times 5$ grid. Pitfalls were separated by $10 \mathrm{~m}$ and replicates within a site were separated by at least $300 \mathrm{~m}$ to ensure independence.

\begin{tabular}{|c|c|c|c|c|c|c|c|c|c|c|c|c|c|}
\hline \multirow[t]{2}{*}{ Site } & \multicolumn{13}{|c|}{ Survey } \\
\hline & Dec. 2008 & Feb. 2009 & Apr. 2009 & May 2009 & July 2009 & Sept. 2009 & Jan. 2010 & Sept. 2010 & Jan. 2011 & Sept. 2011 & Jan. 2012 & Sept. 2012 & Jan. 2013 \\
\hline $08 \mathrm{~N}$ & 1 & 1 & 1 & 1 & 1 & 4 & 4 & 4 & 4 & 4 & 4 & 4 & 4 \\
\hline $10 N$ & 1 & 1 & 1 & 1 & 1 & 4 & 4 & 4 & 4 & 4 & 4 & 4 & 4 \\
\hline $12 \mathrm{~N}$ & 1 & 1 & 1 & 1 & 1 & 4 & 4 & 4 & 4 & 4 & 4 & 4 & 4 \\
\hline $14 \mathrm{~N}$ & 1 & 1 & 1 & 1 & 1 & 4 & 4 & 4 & 4 & 4 & 4 & 4 & 4 \\
\hline $17 N$ & 1 & 1 & 1 & 1 & 1 & 4 & 4 & 4 & 4 & 4 & 4 & 4 & 4 \\
\hline $14 \mathrm{~S}$ & 1 & 1 & 1 & 1 & 1 & 4 & 4 & 4 & 4 & 4 & 4 & 4 & 4 \\
\hline $12 \mathrm{~S}$ & 1 & 1 & 1 & 1 & 1 & 4 & 4 & 4 & 4 & 4 & 4 & 4 & 4 \\
\hline $12 S 2$ & 1 & 1 & 1 & 1 & 1 & 4 & 4 & 4 & 4 & 4 & 4 & 4 & 4 \\
\hline $10 \mathrm{~S}$ & 1 & 1 & 1 & 1 & 1 & 4 & 4 & 4 & 4 & 4 & 4 & 4 & 4 \\
\hline 095 & 1 & 1 & 1 & 1 & 1 & 4 & 4 & 4 & 4 & 4 & 4 & 4 & 4 \\
\hline
\end{tabular}

\section{Appendix 2}

TABLE A2: Checklist of subfamilies and ant species collected during 13 surveys in different broad structural vegetation types across an elevational transect in the western Soutpansberg Mountain Range in South Africa.

\begin{tabular}{|c|c|c|c|c|c|c|}
\hline \multirow[t]{2}{*}{ Subfamilies and species } & \multicolumn{6}{|c|}{ Five broad structural vegetation types } \\
\hline & Woodland & Sedgeland-herbland & Forest & Thicket & Shrubland & Total \\
\hline \multicolumn{7}{|l|}{ Dolichoderinae } \\
\hline Tapinoma sp.01 ?luteum Emery & 121 & 15 & 5 & 0 & 1 & 142 \\
\hline Technomyrmex pallipes Smith & 1143 & 748 & 27 & 44 & 40 & 2002 \\
\hline \multicolumn{7}{|l|}{ Dorylinae } \\
\hline Aenictus rotundatus Mayr & 787 & 0 & 0 & 0 & 7 & 794 \\
\hline Cerapachys UOVC_01 & 1 & 5 & 1 & 0 & 0 & 7 \\
\hline Cerapachys wroughtoni Forel & 0 & 0 & 0 & 3 & 0 & 3 \\
\hline Dorylu shelvolus Linnaeus & 0 & 79 & 2104 & 2 & 193 & 2378 \\
\hline Dorylus UOVC_02 & 45 & 0 & 0 & 0 & 0 & 45 \\
\hline \multicolumn{7}{|l|}{ Formicinae } \\
\hline Anoplolepis cf. custodiens & 92 & 1 & 0 & 0 & 3 & 96 \\
\hline Camponotus cf. niveosetosus & 2 & 9 & 1 & 24 & 6 & 42 \\
\hline Camponotus dofleini Forel & 1 & 1 & 0 & 0 & 0 & 2 \\
\hline Camponotus mayri Forel & 35 & 1 & 0 & 2 & 2 & 40 \\
\hline Camponotus UOVC_02 (rufoglaucus gp.) & 25 & 8 & 7 & 59 & 23 & 122 \\
\hline Camponotus UOVC_03 (niveosetosus gp.) & 0 & 22 & 0 & 0 & 5 & 27 \\
\hline Camponotus UOVC_04 (etiolipes gp.) & 3 & 4 & 3 & 0 & 0 & 10 \\
\hline Camponotus UOVC_05 & 168 & 9 & 0 & 1 & 9 & 187 \\
\hline Camponotus UOVC_06 (maculatus gp.) & 1 & 10 & 6 & 0 & 4 & 21 \\
\hline Camponotus UOVC_07 (empedocles gp.) & 1 & 59 & 0 & 0 & 1 & 61 \\
\hline Camponotus UOVC_08 (mystaceus gp.) & 0 & 1 & 0 & 0 & 0 & 1 \\
\hline Camponotus UOVC_11 (cinctellus gp.) & 5 & 10 & 14 & 58 & 56 & 143 \\
\hline Camponotus UOVC_12 (cinctelus gp.) & 1 & 16 & 0 & 2 & 20 & 39 \\
\hline Camponotus UOVC_17 & 0 & 0 & 1 & 0 & 0 & 1 \\
\hline Camponotus UOVC_18 (maculatus gp.) & 54 & 14 & 16 & 18 & 32 & 134 \\
\hline Camponotus UOVC_20 (niveosetosus gp.) & 11 & 0 & 0 & 0 & 0 & 11 \\
\hline Camponotus UOVC_21 (cuneiscapus gp.) & 7 & 0 & 6 & 0 & 0 & 13 \\
\hline Lepisiota crinita Mayr & 0 & 1 & 42 & 5 & 1 & 49 \\
\hline Lepisiota UOVC_01 (capensis gp.) & 476 & 303 & 79 & 232 & 110 & 1201 \\
\hline Lepisiota UOVC_02 (spinosior gp.) & 57 & 2 & 2 & 0 & 3 & 64 \\
\hline Lepisiota UOCV_08 (capensis gp.) & 72 & 0 & 0 & 0 & 0 & 78 \\
\hline Lepisiota UOVC_09 (capensis gp.) & 0 & 15 & 0 & 0 & 1 & 16 \\
\hline Lepisiota UOVC_10 (capensis gp.) & 6 & 1 & 440 & 0 & 0 & 441 \\
\hline Lepisiota UOVC_11 & 0 & 0 & 1 & 0 & 0 & 1 \\
\hline Plagiolepis UOVC_02 & 40 & 39 & 16 & 1 & 0 & 96 \\
\hline Plagiolepis UOVC_03 & 15 & 29 & 18 & 1 & 0 & 63 \\
\hline Polyrhachis schistacea Gerstäcker & 18 & 0 & 0 & 61 & 20 & 99 \\
\hline
\end{tabular}


TABLE A2 (Continues...): Checklist of subfamilies and ant species collected during 13 surveys in different broad structural vegetation types across an elevational transect in the western Soutpansberg Mountain Range in South Africa.

\begin{tabular}{|c|c|c|c|c|c|c|}
\hline \multirow[t]{2}{*}{ Subfamilies and species } & \multicolumn{6}{|c|}{ Five broad structural vegetation types } \\
\hline & Woodland & Sedgeland-herbland & Forest & Thicket & Shrubland & Total \\
\hline Polyrhachis spinicola Forel & 0 & 0 & 0 & 1 & 0 & 1 \\
\hline Tapinolepis UOVC_01 & 2325 & 0 & 0 & 0 & 25 & 2350 \\
\hline \multicolumn{7}{|l|}{ Myrmicinae } \\
\hline Cardiocondyla UOVC_01 & 3 & 0 & 0 & 0 & 5 & 8 \\
\hline Cardiocondyla UOVC_02 & 4 & 0 & 0 & 0 & 0 & 4 \\
\hline Carebara UOVC_01 & 0 & 5 & 6 & 15 & 2 & 28 \\
\hline Cataulacus UOVC_01 & 4 & 0 & 1 & 0 & 0 & 5 \\
\hline Cataulacus wissmannii Forel & 6 & 0 & 0 & 0 & 1 & 7 \\
\hline Crematogaster UOVC_01 subgenus Sphaerocrema & 359 & 16 & 13 & 2 & 34 & 424 \\
\hline Crematogaster UOVC_02 (rufigena gp.) & 37 & 13 & 7 & 3 & 1 & 61 \\
\hline Crematogaster UOVC_03 (rufigena gp.) & 46 & 4 & 36 & 3 & 10 & 101 \\
\hline Crematogaster UOVC_04 subgenus Sphaerocrema & 31 & 5 & 8 & 0 & 15 & 59 \\
\hline Crematogaster UOVC_05 & 8 & 0 & 0 & 0 & 0 & 8 \\
\hline Meranoplus ?peringueyi & 0 & 218 & 0 & 0 & 0 & 218 \\
\hline Meranoplus cf. glaber Arnold & 128 & 0 & 0 & 0 & 0 & 128 \\
\hline Meranoplus inermis Emery & 0 & 0 & 1 & 4 & 13 & 18 \\
\hline Meranoplus magrettii André & 214 & 0 & 0 & 0 & 7 & 221 \\
\hline Messor UOVC_01 & 0 & 0 & 0 & 42 & 0 & 42 \\
\hline Monomorium ?fastidium Bolton & 163 & 23 & 0 & 0 & 0 & 186 \\
\hline Monomorium ?notulum Forel & 1110 & 83 & 0 & 2 & 1 & 1535 \\
\hline Monomorium albopilosum Emery & 1384 & 2627 & 254 & 118 & 192 & 4575 \\
\hline Monomorium cf. drapenum Bolton & 4870 & 19 & 54 & 12 & 57 & 5328 \\
\hline Monomorium cf. junodi Forel & 0 & 0 & 0 & 785 & 278 & 1063 \\
\hline Monomorium damarense Forel & 1772 & 17 & 9 & 429 & 389 & 2666 \\
\hline Monomorium emeryi Mayr & 22 & 0 & 0 & 0 & 0 & 128 \\
\hline Monomorium UOVC_01 & 8 & 0 & 19 & 0 & 0 & 27 \\
\hline Monomorium UOVC_07 & 20 & 87 & 142 & 11 & 1 & 261 \\
\hline Monomorium UOVC_12 (monomorium gp.) & 13 & 36 & 0 & 1 & 0 & 50 \\
\hline Monomorium UOVC_13 & 47 & 19 & 94 & 3 & 2 & 165 \\
\hline Myrmicaria natalensis Smith & 1375 & 41 & 96 & 512 & 456 & 2480 \\
\hline Ocymyrmex flaviventris Santschi & 153 & 0 & 0 & 0 & 0 & 153 \\
\hline Ocymyrmex fortior Santschi & 2956 & 0 & 0 & 0 & 74 & 3030 \\
\hline Ocymyrmex UOVC_03 & 39 & 0 & 0 & 0 & 0 & 39 \\
\hline Pheidole UOVC_01 (megacephala gp.) & 6097 & 940 & 1248 & 765 & 654 & 9704 \\
\hline Pheidole UOVC_02 (liengmeigp) & 2788 & 20 & 11 & 17 & 42 & 2878 \\
\hline Pheidole UOVC_03 (megacephala gp.) & 2857 & 92 & 1537 & 11738 & 962 & 17186 \\
\hline Pheidole UOVC_05 (megacephala gp.) & 1 & 4807 & 0 & 0 & 0 & 4808 \\
\hline Pheidole UOVC_06 (crassinoda gp.) & 305 & 21 & 1 & 331 & 107 & 765 \\
\hline Pheidole UOVC_07 & 1396 & 27 & 13 & 0 & 0 & 1436 \\
\hline Pheidole UOVC_09 (crassinoda gp.) & 882 & 0 & 0 & 16 & 3 & 901 \\
\hline Pheidole UOVC_10 (megacephala gp.) & 0 & 2835 & 0 & 0 & 0 & 2835 \\
\hline Pheidole UOVC_11 & 0 & 0 & 0 & 0 & 28 & 28 \\
\hline Pheidole UOVC_12 & 5 & 0 & 0 & 0 & 0 & 5 \\
\hline Rhoptromyrmex UOVC_02 & 0 & 14 & 0 & 0 & 0 & 14 \\
\hline Rhoptromyrmex transversinodis Arnold & 0 & 2 & 11 & 32 & 1 & 46 \\
\hline Solenopsis UOVC_01 & 1 & 103 & 115 & 0 & 0 & 235 \\
\hline Solenopsis UOVC_02 & 6 & 9 & 80 & 8 & 0 & 149 \\
\hline Strumigenys ?arnodi Forel & 0 & 1 & 0 & 0 & 0 & 1 \\
\hline Strumigenys pretoriae Arnold & 0 & 2 & 0 & 0 & 0 & 2 \\
\hline Strumigenys UOVC_01 & 2 & 1 & 1 & 5 & 0 & 9 \\
\hline Strumigenys UOVC_02 & 0 & 0 & 1 & 0 & 0 & 1 \\
\hline Tetramorium baufra Bolton & 1480 & 20 & 0 & 0 & 14 & 1514 \\
\hline Tetramorium cf. setigerum Mayr & 64 & 197 & 67 & 49 & 28 & 405 \\
\hline Tetramorium notiale Bolton & 0 & 4 & 18 & 27 & 16 & 65 \\
\hline Tetramorium sepositum Santschi & 489 & 0 & 0 & 0 & 0 & 489 \\
\hline Tetramorium setuliferum Emery & 315 & 38 & 0 & 0 & 2 & 355 \\
\hline
\end{tabular}


TABLE A2 (Continues...): Checklist of subfamilies and ant species collected during 13 surveys in different broad structural vegetation types across an elevational transect in the western Soutpansberg Mountain Range in South Africa.

\begin{tabular}{|c|c|c|c|c|c|c|}
\hline \multirow[t]{2}{*}{ Subfamilies and species } & \multicolumn{6}{|c|}{ Five broad structural vegetation types } \\
\hline & Woodland & Sedgeland-herbland & Forest & Thicket & Shrubland & Total \\
\hline Tetramorium UOVC_01 (squaminode gp.) & 310 & 111 & 137 & 23 & 2 & 583 \\
\hline Tetramorium UOVC_04 (gabonense gp.) & 14 & 0 & 2 & 15 & 87 & 118 \\
\hline Tetramorium UOVC_05 (sericeiventre gp.) & 0 & 3 & 0 & 0 & 131 & 134 \\
\hline Tetramorium UOVC_07 (weitzeckeri gp.) & 201 & 219 & 445 & 447 & 391 & 1703 \\
\hline Tetramorium UOVC_08 (simillimum gp.) & 91 & 96 & 185 & 2 & 31 & 405 \\
\hline Tetramorium UOVC_10 (squaminode gp) & 0 & 174 & 0 & 0 & 0 & 174 \\
\hline Tetramorium UOVC_11 (squaminode gp.) & 6 & 229 & 0 & 10 & 0 & 245 \\
\hline Tetramorium UOVC_12 (squaminode gp.) & 3 & 201 & 969 & 0 & 5 & 1178 \\
\hline Tetramorium UOVC_13 & 0 & 14 & 13 & 13 & 0 & 40 \\
\hline Tetramorium UOVC_14 (sericeiventre gp.) & 0 & 527 & 1 & 0 & 0 & 528 \\
\hline Tetramorium UOVC_16 (sericeiventre gp.) & 0 & 459 & 75 & 0 & 27 & 561 \\
\hline Tetramorium UOVC_17 (simillimum gp.) & 0 & 0 & 3 & 0 & 0 & 3 \\
\hline Tetramorium UOVC_18 (simillimum gp.) & 27 & 2 & 0 & 0 & 0 & 29 \\
\hline Tetramorium UOVC_20 & 0 & 1 & 0 & 0 & 0 & 1 \\
\hline Tetramorium UOVC_21 (squaminode gp.) & 0 & 6 & 4 & 0 & 0 & 10 \\
\hline Tetramorium UOVC_22 & 0 & 0 & 0 & 0 & 3 & 3 \\
\hline \multicolumn{7}{|l|}{ Ponerinae } \\
\hline Anochectus cf. traegaordhi Mayr & 6 & 0 & 0 & 1 & 0 & 7 \\
\hline Anochectus UOVC_01 & 0 & 0 & 5 & 0 & 1 & 6 \\
\hline Anochectus UOVC_02 & 0 & 0 & 1 & 0 & 0 & 1 \\
\hline Bothroponera ?strigulosa Emery & 1 & 2 & 15 & 116 & 8 & 142 \\
\hline Bothroponera UOVC_02 & 0 & 0 & 1 & 18 & 1 & 20 \\
\hline Bothroponera UOVC_03 & 0 & 0 & 0 & 0 & 9 & 9 \\
\hline Hypoponera UOVC_01 & 0 & 1 & 4 & 0 & 2 & 7 \\
\hline Leptogeny sintermedia Emery & 0 & 49 & 8 & 11 & 11 & 79 \\
\hline Leptogenys schwabi Forel & 0 & 7 & 0 & 39 & 8 & 54 \\
\hline Mesoponera ?caffraria Santschi & 2 & 6 & 6 & 39 & 159 & 212 \\
\hline Platythyrealamellosa Roger & 93 & 1 & 1 & 1 & 2 & 98 \\
\hline Platythyrea shultzei Forel & 27 & 0 & 0 & 2 & 0 & 29 \\
\hline Plectroctena ?mandibularis Smith & 2 & 4 & 10 & 0 & 3 & 19 \\
\hline Plectroctena UOVC_02 & 0 & 0 & 2 & 1 & 0 & 3 \\
\hline Plectroctena ?subterranean Arnold & 1 & 0 & 0 & 1 & 0 & 2 \\
\hline Ponera UOVC_01* & 1 & 0 & 2 & 0 & 0 & 3 \\
\hline Pseudoponera UOVC_01 & 7 & 4 & 0 & 0 & 4 & 15 \\
\hline Pseudoponera UOVC_02 & 0 & 0 & 0 & 0 & 4 & 4 \\
\hline \multicolumn{7}{|l|}{ Psedomyrmecinae } \\
\hline Tetraponera UOVC_01 & 2 & 1 & 0 & 0 & 0 & 3 \\
\hline
\end{tabular}

UOVC, University of Venda Collection.

*, Introduced species. 


\section{Appendix 3}
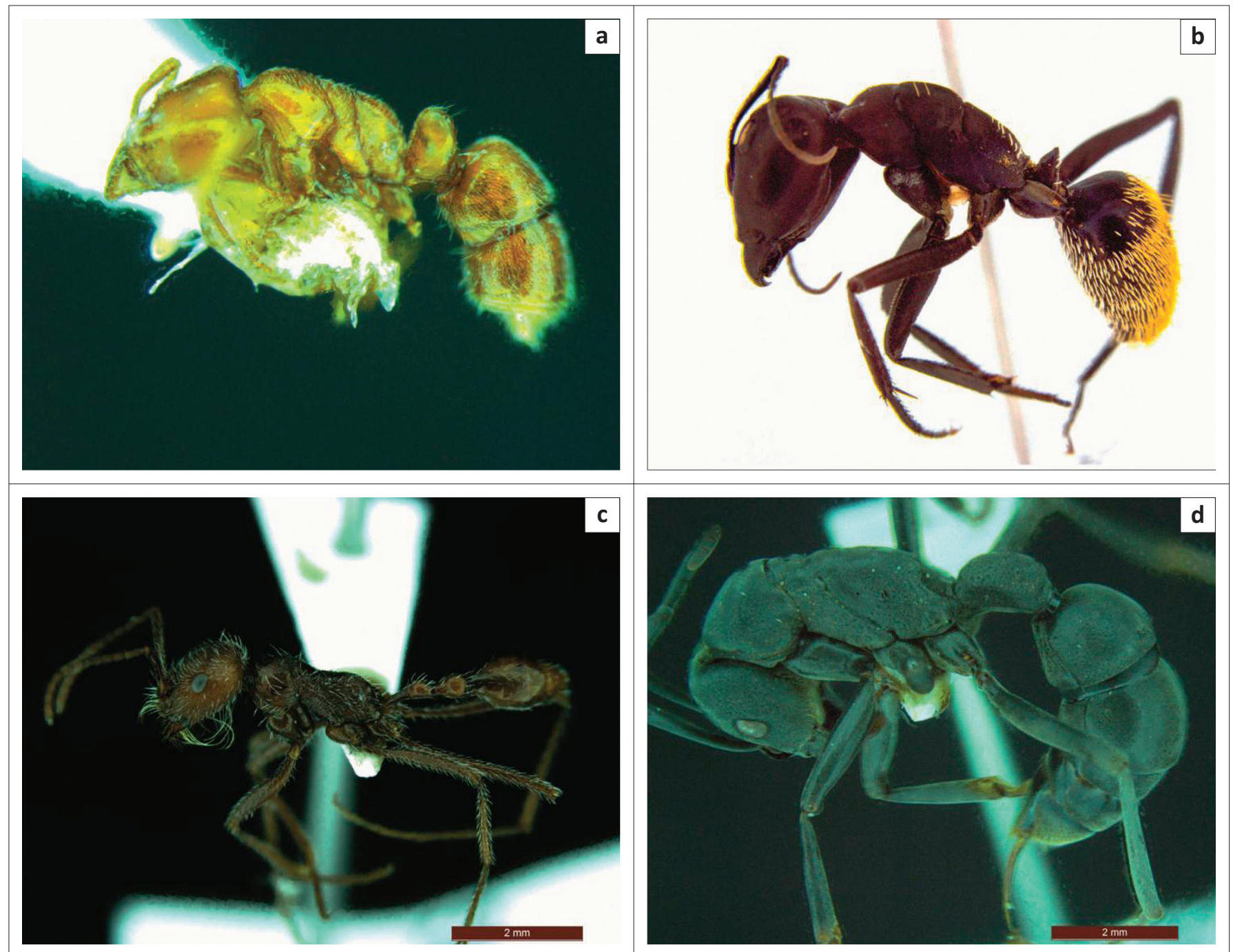

FIGURE A1: Images of some notable and interesting species collected during 13 surveys: (a) Introduced species Ponera UOVC_01, (b) Camponotus fulvopilosus De Geer, (c) Ocymyrmex flaviventris Santschi and (d) Platythyrea lamellosa Roger. 